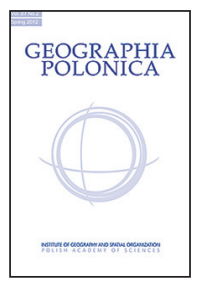 \\ INSTITUTE OF GEOGRAPHY AND SPATIAL ORGANIZATION \\ POLISH ACADEMY OF SCIENCES \\ www.igipz.pan.pl \\ www.geographiapolonica.pl
}

\title{
A VISION FOR A FUTURE EUROPE ACCORDING TO A RUSSIAN MAP OF 1914
}

\section{Piotr Eberhardt}

Institute of Geography and Spatial Organization

Polish Academy of Sciences

Twarda 51/55, 00-818 Warsaw: Poland

e-mail: p.ebe@twarda.pan.pl

\begin{abstract}
In this article, a map published and popularized in Moscow at the end of 1914 is presented and analyzed from a cartographic and factual perspective. Drawn up on the initiative of the highest Russian authorities, the map presents the post-World War One political system in Europe as envisaged by the author. He believed that, in the aftermath of a victorious war for Russia, the significant shifts of political boundaries in Europe which are shown on the map would take place. The cartographic document in question thus constitutes interesting historic evidence attesting to the expansionist ambitions of the Russian Empire of that time.
\end{abstract}

\section{Key words}

Russia - World War One - political boundaries in Europe

\section{Introduction}

In the initial phase of World War One a map published in Moscow and then distributed across the entire Russian Empire bore a title making the intention of the map designer entirely clear. The map in question presented the envisaged post-War boundaries of European countries, and it was entitled Karta budushchey Yevropy (The map of the future
Europe, Fig. 1). However, the main title was accompanied by a jokingly formulated subtitle: Kak yego ne dumal videt Vilhelm tsar Evropeyski (As it has not been thought of by Wilhelm, the Emperor of Europe). The continent of Europe is sketched with new political boundaries expected to take shape in the aftermath of the defeat of the German and Austro-Hungarian Empires, and hence the victory of the countries forming the Entente 


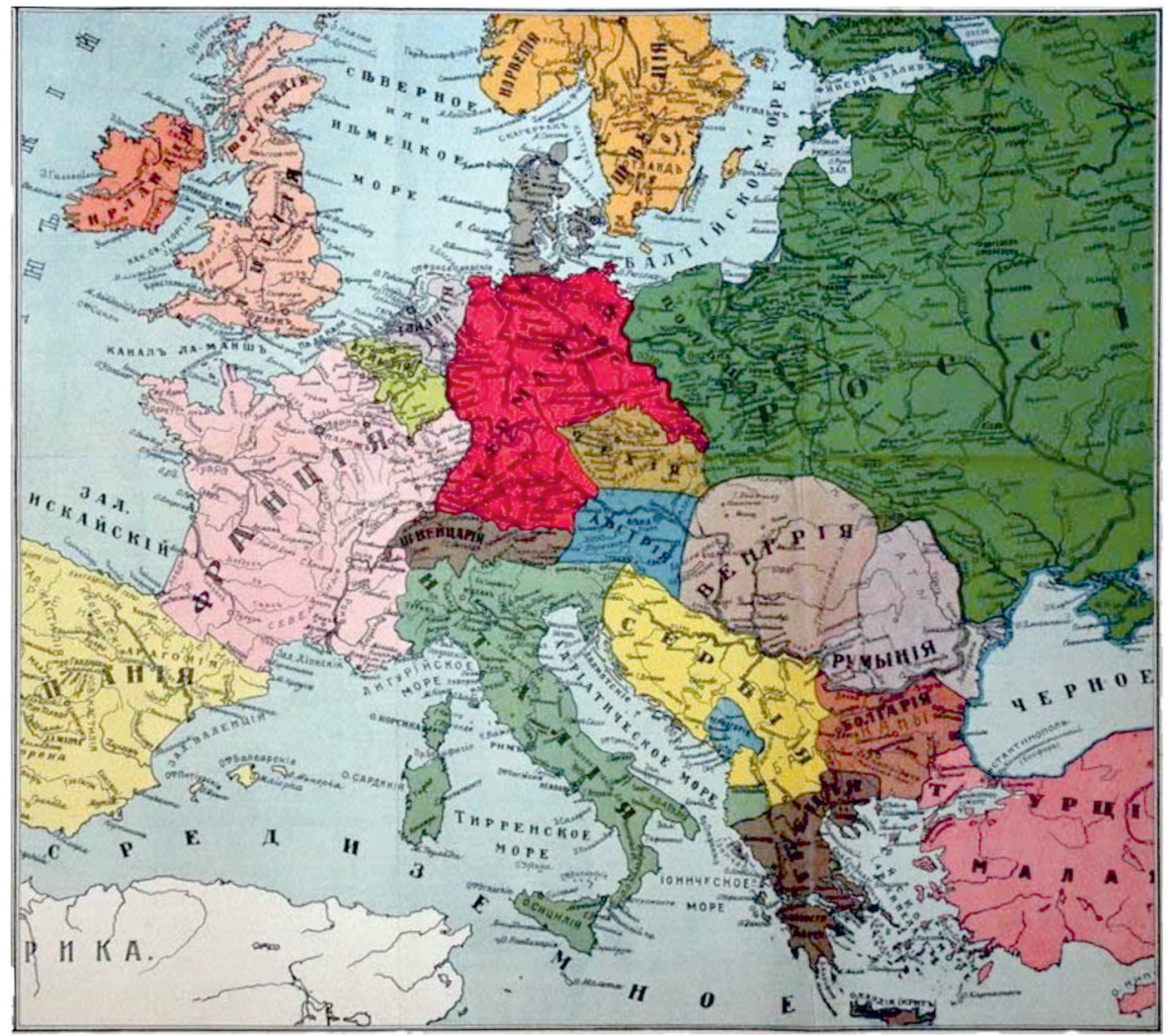

Figure 1. Karta budushchey Yevropy (The map of future Europe)

Source: I.P. Alexeev, 1914

Cordiale - above all (naturally enough) - Russia.

The available copy of the map offers no information as to authorship, and so was apparently an anonymous work. There are nevertheless definite and quite sound premises for suspecting that the map appeared on the initiative of the Foreign Office of Russia, as headed at that time by Sergey Sazonov. Above all, it is well known that such a cartographic document could not have been published in wartime without the consent of the highest authorities. Furthermore, the proposed boundaries of European countries are marked on this map in a quite precise manner, and it has been assumed - justifiably - that the effect of the War would be to bring about very significant shifts in borders. It was anticipated that the victorious countries would make significant gains in territorial terms at the expense of those defeated. There are no doubts that the winning side would be that of the Entente - first and foremost Russia. All of the annexation claims of the potential winners are accounted for on the map. There are also numerous, short and concise remarks within the broad margin of the map. These are in the nature of explanatory comments, and all conform with official declaration of Sazonov, announced on 13 September, 1914, and then published in the governmental press. These annexation proposals were presented to the ambassadors of the United Kingdom and France, accredited in the capital city of Petrograd. The respective actions were conducted in concert, since during the entire War Russia demanded freedom as to the establishment of the new boundary with 
Germany and Austria, not questioning the right of the Western Powers to determine the post-War western boundary of Germany. This kind of agreement was accepted on both sides, and did not give rise to any reservations among the countries of the Entente Cordiale.

The map presented, whose publisher was I.P. Alexeyev (?), was printed in Moscow, at 4 Nizhna Kislovka Street. There is a lack here, not only of visible authorship, but, also of any publication date. It can only be supposed that it was published before the beginning of November 1914, when Turkey entered the European military conflict. This can be deduced from a warning on the margin of the map, addressed to Turkey, and urging it not to side with Germany in the European war.

The cartographic document recalled here was not official in nature, since it was not undersigned by any state institution with the appropriate authorisations to do that. However, this fact should not be taken to disqualify the document as historical evidence, since it definitely appeared with official consent, and perhaps even at the inspiration of the chief military and state authorities of Russia, who made no secret at all of their political and territorial intentions and demands. A relatively swift victory over the Central Powers was expected, and complete defeat of the enemy would be followed by a rectification of the political boundaries, in such a way as to first and foremost seal in significant territorial gains for Russia. The map considered thus offers an illustration of Russia's imperial plans with respect to her enemies and neighbours. However, implementation of those plans always depended on the outcome of the War, and this did not as it turned out take a course that conformed with the optimistic expectations of the Russian General Headquarters. The defeat of the two Russian Armies in East Prussia, and the gradual retreat from the territory of the so-called Polish Kingdom, rendered the elaborated plan for territorial change in Europe obsolete. Hence, as time passed, the map lost both its political and propaganda qualities.
The military failure and movement of German troops eastward brought about a shift in the stance of the Russian authorities. A difficult internal situation also toned down the greed on the part of the Russian power elite. It became increasingly reasonable to forward the concept of a return to the pre-War boundaries as of 1914. A reinstatement of imperial territorial programs could have been harmful for Russian interests. Hence the map was withdrawn from public circulation and was never brought back out again. The Russian side instead increased its efforts to achieve a preservation of the pre-War status quo. However, later events associated with the Revolution and the downfall of the Tsarist regime left the map altogether outdated. The peace agreement signed in Brest confirmed the total military defeat of the Russian state. Under conditions transformed thus, the map in question lost its political value and was relatively quickly forgotten by historians and geographers alike. The rich literature concerning the period of, and events linked with, World War One in fact makes only a few mentions of the annexation plans of Russia, given that these were of no political consequence. For the very same reason, there was a withering-away of knowledge regarding the existence of the map published in 1914, and of its ideological and geopolitical implications.

It is most probable that the first Polish scholar to submit this cartographic and political work to a general scientific interpretation was Rosen-Zawadzki (1972). In the paper he published, he provided a reproduction of the map in a rough black-and-white rendition that is not easily legible. It was this cartographic image that attracted the attention of the present author, albeit with a sole focus on those boundaries relevant to the Polish lands (Eberhardt 2008, 2009)1. It was the view - and presumably the intention - of the authors of the map that Poland would be deprived of its sovereignty, instead acquiring

\footnotetext{
1 These two papers provide a broad bibliography relating to the origins and historico-political conditioning of the cartographic document in question.
} 
the status of an autonomous province under the Russian Empire.

In its original version, the map was coloured, and it has now become possible to produce a rendition of it in line with these original colours. This fact allows for a better cognition and interpretation of the now-fully-legible cartographic document. However, for reasons of size, the reproduction does not contain the margins mentioned before, wherein the Russian-language comments were placed with a view to explaining the proposals put forward as regards shifts in boundaries and the ultimate post-War shape of the political map of Europe. The complete set of comments can be read out from the reproduction attached to the paper by K. Rosen-Zawadzki referred to before. Some of these comments will be referred to here, since they explain the motivations of the designer of the cartographic document analysed. Given that these comments reflect the attitudes of the Russian authorities, they have not lost their pronounced historical significance.

In the substantive analysis of the map in question it is hard to determine the extent to which map content expresses the personal views of Minister Sazonov, or else the extent to which it represented the views of other leading politicians or the military. Knowing the character of relations in Russia, one can suppose that the decision to publish the map was by no means incidental, and was taken collectively at the highest level of authority. The ideological and political meaning of this document is unambiguous. After having defeated her enemies, Russia intended to engineer a radical shift in the borders of European countries. Central Europe was to differ significantly from the version designed during the Vienna Congress of 1815 , which lasted for close on one hundred years in an almost unchanged shape.

The primary objective of the War in which Russia became involved was to dismember, and, in principle, to annihilate, the AustroHungarian Empire, while also diminishing the German Empire in terms of territory occupied. The latter was to be reduced to the rank of a secondary country, over which the powerful Russia might hold sway. It was naturally enough Russia that was to be the chief beneficiary of the War, and was emphasised throughout that the struggle of Russia with the Germanic universe was fully justified, since the Russian authorities were not motivated by cynical political interest, but only demanded respect for justice and the wish that all European nations would enjoy the same right to freedom and sovereignty. There is a comment on the map in this spirit, explaining the message quite unambiguously. Given the colourful rhetoric of this comment, which got repeated afterwards in the multiplicity of various Russian and Soviet declarations, it is definitely worth quoting: The "Great and self-dependent Russia wages war for the rebirth of law, justice, peace and orderliness on the Earth. She does not need foreign property, she wants no alien lands, she shall only take what she fully deserves: Red Ruthenia with Lvov and Przemyśl, a part of Bukovina with Chernivtsi. East Prussia, together with Königsberg, soaked many times over with Russian blood, shall become again the Russian land, up to the Vistula river. They should become anew the Russian fortresses." This quotation is not jut tendentious, but also entirely untrue. None of the provinces mentioned, i.e. the so-called 'Red Ruthenia', Bukovina and East Prussia, and none of the cities listed - Lvov, Przemyśl, Królewiec, and Chernivtsi - ever belonged to Russia. Below the text quoted before, but still within the framework of the part devoted to Russia, we find the formulation "Poland shall unite her provinces, dismembered until now by the evil plots of Germany and Austria." 2

In conformity with the map considered, Germany would lose to Russia East Prussia, Western and Gdańsk Pomerania, Wielkopolska, as well as Upper and Lower Silesia to the East of the River Odra - this river intending to become the Russian-German border along

\footnotetext{
2 For more about these designs, see Eberhardt $(2008,2009)$. Here, mention of the German and Austrian plots is particularly cynical, since it was Russia that was the main instigator of the partitioning of Poland.
} 
its entire course. In the West, the GermanFrench border would, following the victorious war, be moved up to the Rhine. This would imply Germany's loss, not only of Alsace and Lorraine, but also of the entire territory situated between the Rhine and Mosel, along with Coblenz. Given the resistance to the march of German armies seeking to attack France, the author of the map is very magnanimous with regard to Belgium. Thus, Belgium was supposed to gain - after the victorious war was over - significant compensation at the expense of German territory. The entire area between the Mosel and Rhine would thus be incorporated into Belgium. Similarly, significant territorial gains were intended for The Netherlands. The North Rhineland with the city of Essen, in which the arms factories of the Krupp company were located, would have become an integral part of The Netherlands. A shift is also postulated where the German-Danish boundary is concerned, this needing to be pushed far southwards, down to the Kiel Canal.

However, the German Empire was to be preserved, if in significantly reduced shape much recalling the so-called Potsdam Germany of 1945. On the other hand, liquidation was assumed in the case of Austria-Hungary, or ultimately its transformation into a tripartite Hapsburg monarchy, composed of a proper Austria, Czechia, and Hungary. However, the map shows distinct political divides, cutting Austria-Hungary into several independent countries, notably Czechia with Moravia, as well as Cieszyn and Opava Silesia. The expected new boundaries of the Hungarian state are also shown - with eastern Transylvania (Siebenbürgen) lost, but with preservation of Hungary proper, Slovakia, Vojvodina, and western Transylvania. Russian sympathies for the Eastern Orthodox Serbia found a reflection in a proposal for advantageous boundaries for this country. So a 'great' Serbia was supposed to emerge from the World War, including Croatia, Dalmatia, Bosnia, Herzegovina, and the western part of Macedonia, which was supposed to be split between Serbia, Bulgaria, and Greece. On the other hand, Slovenia was to be incorporated into Italy. The remaining skeletal Austria was also to be deprived of Tirol, to the advantage of neutral Switzerland. This proposal was justified by resort to a rather surprising argument entailing apprehension on the part of Russian tourists as regards visits to Alpine spas and resorts in the inimical Austria. The Kingdom of Romania was then to be extended to include southern Bukovina and eastern Transylvania. Further, a liquidation of Albania was envisaged, with a split proposed between Serbia, Montenegro and Italy. Bulgaria was to regain eastern Thrace, lost as a result of the second Balkan war, and in this way gain access to the Aegean Sea.

The information provided, contained on the map reproduced here except for the comments on the margin, implies that Russia intended to pursue, after its victorious war, truly revolutionary changes in the political divisions in Europe. This was to be associated, not only with a westward shift of the boundaries of the Russian Empire, but also with the liquidation of some of the existing political entities, and the establishment of certain new ones. All of the proposals as regards territory that have been listed gain justifications in the short, concise comments made to the left of the map. These are of an authoritarian character, offering evidence as to the authors' conviction regarding the enormous military power of Russia, and the requirement that her world-power ambitions be satisfied. The major undertone is a certainty that it is Russia that would be predisposed to decide on the European continent's future fate.

It is now hard to discern if the suggested design for the future configuration of European borders, as developed by Sazonov's circles was a futurologist's vision and completely utopian, or did rather have tangible chances of being turned into reality. The answer is difficult, as always in the case of visions whose high probability of realisation still fails to denote actual fulfilment for some reason or other. Considerations of their degree of reality have a more journalistic character and belong to what is referred 
to as alternative history. However, it should be noted that, at the moment, of distribution of the map (the end of 1914), none knew what the closer or more-distant future could bring. In this initial phase of war, the defeat of Russia was not really taken into account by any objective and impartial observers of the then political scene. Russia had at its disposal, not only the largest landed army in the world, renowned for its military effectiveness, but also very strong allies in the shape of France and Britain). The Central Powers were surrounded and obliged to fight on two fronts. After the Schlieffen Plan collapsed, and a military failure over the Marne ensued, the situation of Germany became very difficult, and - as the fighting continued, and especially as the United States joined the military operation - began to look hopeless indeed. Hence, it can be supposed that, had it not been for the Revolution and the collapse of state structures, Tsarist Russia would have persisted until the Peace Conference in Versailles, among the victorious powers. Further, in such circumstances, the voice of Russia would have been decisive where political solutions concerning Central and Eastern Europe were concerned. In line with the declarations made previously, the Western Allies would not have questioned Russia's right to territorial gains and her boundary-related demands with respect to the defeated Germany and Austria-Hungary.

It is beyond doubt that the design shown here, presenting a spatial setting to post-war boundaries in Europe, was among the more realistic of then geopolitical concepts. This reflects a construction on the basis of quite plausible premises, in line with the military strength of all countries participating in the European conflict, and the existing political alliances. The implementation of such a vision was thus capable of appearing highly probable, and it was rather the abolition of the Tsarist regime and the disintegration of the Russian Army that were unexpected facts, hardly envisaged by analyses. The spectacular downfall of the Russian Empire surprised even Germany's military leaders, notwith- standing their very serious treatment of their eastern enemy's power. They took advantage of the revolutionary ferment, which they also stimulated effectively. ${ }^{3}$ As a result of de facto defeat in the War, Russia lost Finland, the three Baltic countries (Lithuania, Latvia and Estonia), Poland, and Bessarabia. It was only the later victory of the Soviet Union over Nazi Germany that brought the possibility of territorial compensation and of a regaining of the lost countries and provinces, and even of the achievement of political domination over territory stretching between the Baltic, Adriatic and Black Seas that was not envisaged by even the most optimistic visions of the Tsarist power elite. Subordination of the whole Central-Eastern European region and the obtainment of superpower status thus took place after a 30-year delay, and of course in entirely different geopolitical conditions.

The unexpected events transforming the Russian Empire from the inside brought about a rapid loss of significance where the map published in 1914 was concerned. It abruptly lost its hands-on value and became an archival document, though one that always retained its cognitive value. It shows in a very pungent manner the imperial tendencies of the Russian state, which are inherent in nature. Moreover, the map is extremely interesting in both substantive and cartographic terms, as it constitutes a unique item of historical evidence worthy of in-depth analysis as regards both the geographical and political sciences. There are not so many examples in the geopolitical literature of such visionary maps questioning the existing political division of Europe, and proposing its radical reconstruction. It renders quite faithfully the imperialist intentions of Russia, as regards nearer and more-distant neighbours alike. It is seen to reflect how, irrespective of the economic and political system, and even changes in the nature of the rhetoric applied, the goals of the Russian Empire remain unchanged, with a constant desire

\footnotetext{
3 In April 1917, the German General Headquarters organised the transport of Lenin and 70 of his companions from Switzerland, through Germany and Sweden, to Petrograd.
} 
to achieve territorial expansion and political domination.

After Crimea was incorporated into the Russian Federation in 2014, the later Ukrainian-Russian military conflict proceeded in connection with an officially proclaimed idea that appeared in the matter of the liberation by Russia of the so-called New-Russia, with some $1 / 3$ of the entire territory of Ukraine being incorporated into Russia. In such circumstances, fresh reference to this particular map from a century ago seems frighteningly apposite. As mentioned, in regard to the political and territorial principles, the imperial plans of old Russia remain mostly unchanged. Irrespective of the form of government, the authorities in the Kremlin seem to uphold traditions associated with imperial and superpower ambitions, consistently pursuing a policy of expansion and enforced domination. The programme in question

\section{References}

EBerhardt P., 2008. Projekty aneksyjne Cesarstwa Rosyjskiego wobec ziem polskich podczas / wojny światowej [in:] P. Eberhardt (ed.), Problematyka geopolityczna ziem polskich, Prace Geograficzne, 218, Warszawa: Instytut Geografii i Przestrzennego Zagospodarowania PAN, pp. 151162.

Eberhardt P., 2009. Kształt terytorialny Polski według mapy rosyjskiej (1914) i sowieckiej is being implemented cyclically, in relation to the current geopolitical conditions and the actual possibilities for further implementation. In neither dimension are the aspirations constrained by either legal or moral barriers, as is evidenced by ongoing current (2015) events in Ukraine. That is why analysis of the map published in 1914 and showing the postulated boundaries of the Russian Empire, acquires political significance even beyond its historical significance.

Presented exactly one century after its elaboration and issue, the map under consideration here is beyond doubt exceptional in terms of both content and form, and its ideological message explains many political events taking place during the 20th century. In view of its originality, it is a historical document of high value, and should be subject to further studies from specialists dealing with geopolitical concepts and doctrines.

(1944). Studia z Dziejów Rosji i Europy Środkowo-Wschodniej, vol. 44, Warszawa: Polska Akademia Nauk. Zakład Dziejów Europy XIX i XX wieku, Wydawnictwo Naukowe Semper, pp. 249-264.

Rosen-Zawadzki K., 1972. Karta buduszczej Jewropy. Studia z Dziejów ZSRR i Europy Środkowej, vol. 8, Warszawa-Wrocław: Polska Akademia Nauk. Zakład Historii ZSRR i Europy Środkowej, Zakład Narodowy im. Ossolińskich, pp. 141144. 
http://rcin.org.pl 